\title{
THE ISSUE OF TEACHING FAMILY SPEECH OF THE GERMAN LANGUAGE CONSIDERING THE DOMINANT COMMUNICATION FEATURES OF THE GERMANS
}

Sevara Ziyayeva

Ph.D., Associate Professor at the Uzbek State World Languages University

http:/ /dx.doi.org/10.26739/2573-5616-2018-1-2-13

Abstract. The article reveals the thesis on teaching German to students of philological departments at higher educational institutions the ability to effectively use of the German language in the social (family) context can be developed and appropriately implemented only based on already learnt knowledge of the dominant features of German communication.

Key words: social dialect, family speech, cultural concept, dominant features of communication, verbal behavior, social context.

The norms of speech behavior are one of the main components of the sociolinguistic competence of the students-philologists who are studying the German language. The knowledge of skillful and appropriate application of the rules of speech production is the criterion for the formation of their sociolinguistic

Generalization of scientific results 
competence, presupposing the construction of speech, taking into account the situation of the context, the status of communicants, their social roles, social distance between them, their age, gender and other circumstances that determine the choice of appropriate linguistic means of expression.

In this article, we consider the need to encounter the dominant features of German communication when teaching their family speech to students of philological departments of universities teaching German.

Studying by the students-philologists norms of speech behavior of the German people in various social dialects, including family speech, has its own peculiarities, which consist, on the one hand, in the non-identity of speech behavior of speakers in different social and communicative contexts of communication, on the other hand, the parties i.e. in the allocation of certain "through", dominant features of communication, characteristic of speech behavior of all representatives of the nation, and thirdly, in the existing similarities and differences in the norms of speech behavior in German and our native Uzbek languages.

In our opinion, when learning German as a foreign student of philological departments at higher educational institutions, the ability to effectively use of the German language in a social context can be developed and appropriately implemented only, on the basis of the already developed skills of the dominant features of German communication, in general.

For instance, the dominant features of German communication radically differ from the dominant features of communication of the Uzbek people. These differences are due primarily to the fact that "the Germans care about protecting their territory. Moreover, the inviolability of foreign territory is also important for them, therefore, the Germans are reserved in their communication, they share with small portion of information like "I do not know" to many questions that do not directly concern their studies. In the German linguistic and cultural community, it is not accepted to interfere in the business of others, to address requests to strangers" [Gazizov, 2010, p. 103].

The Uzbek people, on the contrary, are very talkative and attentive to the interlocutor, hospitable. It is customary to greet handshakes among the Uzbeks even with unfamiliar people, and in some situations they even kiss. Moreover, when they ask a stranger a question or make a request, they try to explain the answer in an amicable way, and in cases of ignorance of the answer, they Generalization of scientific results 
apologize and in order to help a person turn to a stranger interested in the question themselves. The Uzbeks will not leave a stranger who asked them (a request) until they are convinced of the solution of his problem.

Naturally, such differences in the dominant features of communication between the Germans and the Uzbeks must necessarily be considered by the students-philologists when building a speech in German addressed to the representatives of the German nation.

The public behavior of the Germans, their way of thinking, their outlook are predetermined in many ways by the culture of this people, the main concept of which is "request". The desire for order determines the inherent characteristics of the Germans, such as punctuality, concentration, responsibility, accuracy, cleanliness, etc. The main concept of Uzbek culture is the "Family", and all life activity of Uzbeks in all spheres of functioning is realized through the prism of this concept and outlook, it is not for anything that the national values of the Uzbek people are such things as respectful attitude to parents, and respect for elderly people, makhalla ("We are one big family!"), etc.

What is the family in the minds of the German people? As G. A. Gunyasheva states "the process of family life / Zusammenleben in the representations of the German ethnos is dynamic, proceeds in time and space and is conceptualized by various activities: coexistence, living with someone, farming, establishing life and relations within the family collective, the birth and upbringing of children, etc." [Gunyasheva, 2012, p. 155].

The interpretation of the family life process is carried out by the German people in the following models:

1) family is creation (construction);

2) family is the way (journey);

3) family is war;

4) family is the game;

5) family is theater;

6) the family is an economic enterprise;

7) the family is the state;

8) family is school;

9) family is an experiment [Gunyasheva, 2012, p. 155-57].

A harmonious family for the German people is "the result of intense creative activity, work, joint efforts of all members of this small social group, the success Generalization of scientific results 
of the family in its cohesion, the ability to organize the functioning of the family in the internal and external society" [Gunyasheva, 2012, p. 158]. The family traditional values for the Germans are "love and the pursuit of order, the denial of spontaneity and uncontrollability of processes, the desire to streamline, regulate, control" [Gunjasheva, 2012, p. 158].

It is easy to see that the key concept of German culture "request" has a direct impact even on the relatively personal space of the sphere of human life is the process of family life.

In this connection, Medvedev points out that "everything that is clearly not allowed is considered illegal in Germany, and citizens are informed about this by means of prescriptive announcements. The Germans are inclined to distinguish everything: private life and official, the delimitation of one concept from another, one moment of time from another and even types of waste - biological and poisonous, types of glass by its color "[Medvedev, 2007, p. 110]. In Uzbeks, the perception of the world is different: everything that is clearly not forbidden can be considered resolved. In Uzbekistan, you will not see prescriptive ads: they only write about things that are not allowed. This state of affairs gives relative freedom to the actions of a person, unravels him; the concept of order is not so categorical and principled.

A. G. Smirnova, investigating the language of the family sociolect in the modern German language: the genre features of varieties of family speech, the lexical composition, extra linguistic factors influencing the construction of family speech, in the work "Functional-stylistic originality of family speech (on the material of the German language)"; behavioral stereotypes, strategies, tactics; features of children's speech, comes to the conclusion that the family speech of the Germans is characterized by intimacy, confidence in tone, its vocabulary, its subject matter, its customs and rituals, mutual understanding with a half-word [Smirnova, 2008, p. 3]. But despite this speech behavior in the family circle is carried out within the prescribed roles: the senior - the younger, the child - the parent, where the speech of adults is mostly the nature of orders and instructions [Smirnova, 2008, p. 3-7]. That is, in other words, even in family relations, priority is given to order: everything must be hierarchical, traditionally, everyone should know their place and fulfill their family responsibilities.

Naturally, with this approach to family relations, speech will be characterized by "restraint in the manifestation of genres of a compliment, praise,

Generalization of scientific results 
it is more neutral and less emotional than, for example, Russian" [Smirnova, 2008, p. 17-8], and the lexical and syntactic features of the linguistic and linguistic characteristics of the family, ethnicity, language, the organization of modern German family speech is conditioned by "some closeness, intimacy of the family sphere" [Smirnova, 2008, p. 3]. At the heart of the same closed and intimate family sphere of Germans lies, in turn, their desire to protect and inviolate their territory.

Thus, the student-philologists studying the German language should take into account that the specific features of speech behavior in the family circle, as well as in other social dialects, are formed on the basis of the dominant features of German communication in general. Knowledge of the dominant features of German communication will make it possible to more effectively understanding and production of their speeches in German in various social and communicative contexts. 
American Journal of Research

№ 1-2 (1-2), January-February 2018

DOI 10.26739/2573-5616 www.journalofresearch.us

info@journalofresearch.us

Print - 2573-5616; Online - 2573-5624

\section{REFERENCES}

1. Gazizov R.A. Max tact in terms of linguistic courtesy (on the material of the German language). // Bulletin of Volgograd State University. Series 2. Linguistics. - № 2 (12), 2010. - C. 97-104. Газизов Р.А. Максима такта в аспекте лингвистической вежливости (на материале немецкого языка). // Вестник Волгоградского государственного университета. Серия 2. Языкознание. - № 2 (12), 2010. - C. 97-104.

2. Gunyasheva G.A. Interpretation of the axiological characteristics of the concept FAMILIE through conceptual activity metaphors. / / Bulletin of KemSU, No. 4 (52), T. 3, 2012. - P. 155-158.Гуняшева Г.А. Интерпретация аксиологических характеристик концепта FAMILIE посредством концептуальных деятельностных метафор. / / Вестник КемГУ, № 4 (52), Т. 3 , 2012. - C. 155-158.

3. Medvedeva T.S. Representation of the ORDNUNG concept in the German language picture of the world. / / Bulletin of the Udmurt University. No. 5 (2), 2007. - Р. 105-114.Медведева Т.С. Репрезентация концепта ORDNUNG в немецкой языковой картине мира. // Вестник Удмурского университета. - № 5 (2), 2007. - С. 105-114.

4. Smirnova A.G. Functional-stylistic originality of family speech (on the material of the German language): Author's abstract. diss. ... cand. philol. sciences. - Moscow, 2008. - 19 р.Смирнова А.Г. Функциональностилистическое своеобразие семейной речи (на материале немецкого языка): Автореф. дисс. ... канд. филол. наук. - Москва, 2008. - 19 с.

Generalization of scientific results 